No. 23666; C. K. Allen. Common in waste ground and undisturbed meadows.

Lactuca canadensis L. WILD Letruce. Nos. 23626, 28095. Common in meadows and waste ground.

Lactuca spicata (Lam.) Hitche. Tall Wild Lettuce. No. 23649; Grigg $\&$ Palmer. Frequent in low meadows and borders.

Prenanthes alba L. Rattlesnake-root. No. 23648; C. K. Allen. Abundant in open woods, especially on low glacial hills along Meadow Road.

${ }^{*}$ Hieracium aurantiacum L. Devil's Paint-Brush. C. K. Allen. Infrequent in meadows and along paths.

*Hieracium Pilosella L. Mouse-Ear. No. 25823; C. K. Allen. Local along grassy path in Shrub Collection.

*Hieracium pratense Tausch. King Devil. F. W. Grigg. Meadows.

Hieracium venosum L. Poor Robin's Plantain. Nos. 27958, 28183. Locally abundant in rocky woods, south side of Hemlock Hill and in woods along South Street.

Hieracium paniculatum L. Tall Hawk-weed. Nos. 25959, 28217. Local on rocky slopes, south side of Hemlock Hill.

Hieracium scabrum Michx. Rough Hawk-weed. Nos. 23669, 28218. Not rare locally in rocky woods.

\title{
A SECOND SUPPLEMENT TO THE FLORA OF BARRO COLORADO ISLAND, PANAMA \\ Paul C. Standley
}

It is a great source of satisfaction to all scientists interested in the study of the natural history of tropical America in general, and of Central America in particular, to read the entertaining annual reports of the Laboratory for Tropical Research, established on Barro Colorado Island in Gatún Lake in the Panama Canal. Each year shows an increase in the number of investigators who make the laboratory the headquarters for their work. These fortunate students must be envied by the less happy of us, who are forced to spend our winters shut indoors in the cold North.

The increased use being made of this laboratory, so delightfully situated and so comfortably-compared with the quarters usually obtainable in the tropics, one is tempted to say luxuriously-equipped for conducting investigations, is the natural result of the reports brought back by visitors. Sufficient credit will never be given to Dr. Thomas Barbour and Mr. James Zetek for their persistent efforts, in spite of many discouraging obstacles, to make the station a success.

An unusually large number of persons interested in plants visited Barro Colorado in 1929, and several of them made substantial collections of herbarium specimens, which the writer has been privileged to determine. These collections were made by Professor S. W. Frost, of Pennsylvania State College; R. H. Wetmore and R. H. Woodworth, of the Botanical 
Museum of Harvard University; and W. N. Bangham and F. M. Salvoza, graduate students of Harvard University. Mr. Bangham's series is one of the finest ever obtained on the island. His specimens are well prepared and complete, and either he visited the locality at an exceptionally favorable season, or else he had a knack of detecting plants overlooked by previous collectors. At any rate, his collection, forwarded to the writer for study from the Arnold Arboretum, contains a surprising number of species new to Barro Colorado, several new to the Canal Zone, and seven which seem to be undescribed.

Mr. Salvoza's collection practically duplicates that made by Mr. Bangham, and the specimens were determined by the collector in comparison with the named set of the latter's plants. Although I have received a list of his numbers, it has not seemed altogether desirable to cite them here, since I have not actually seen the specimens. A few of Mr. Salvoza's specimens which I have examined are listed.

In connection with the descriptions of these new species, it is worth while to list all the additions made in 1929 to the known flora of Barro Colorado Island, which has been recorded by the writer in two published papers. ${ }^{1} \quad$ There have been listed heretofore 799 species, chiefly of flowering plants. On the following pages there are reported 63 additional ones, making a very respectable total of 862 . It is predicted confidently that this number will be greatly increased by further careful exploration. It is urged particularly upon workers who visit the island that they collect the mosses and other cryptogamic plants.

\section{MOSSES}

Determined by Edwin B. Bartram

Philonotis tenella (C. M.) Besch. This and the following, collected by Professor L. A. Kenoyer, were omitted accidentally from the first supplement.

Syrrhopodon incompletus Schwaegr.

\section{POLYPODIACEAE}

\section{Determined by C. A. WeAtherby}

Acrostichum aureum L. Wetmore \& Woodworth, no. 102. A coarse, widely distributed tropical fern, growing usually in shallow water.

Asplenium auritum Sw. Wetmore \& Woodworth, no. 132.

Asplenium falcinellum Maxon. Wetmore \& Woodworth, no. 129.

Asplenium pteropus Kaulf. Wetmore \& Woodworth, no. 133.

Blechnum serrulatum Rich. Wetmore \& Woodworth, no. 149.

Dryopteris nicaraguensis (Fourn.) C. Chr. Wetmore \& Woodworth, no. 128.

${ }^{1}$ Paul C. Standeey, The flora of Barro Colorado Island, Panama. (Smithson. Misc. Coll., vol. 78, no. 8, pp. 1-32. 1927.)

Leslie A. Kenoyer and Paul C. Standley, Supplement to the flora of Barro Colorado Island, Panama. (Field Mus. Bot. 4: 143-158, pl. 11-15. 1929.) 


\section{MARANTACEAE}

Myrosma guapilensis Donn. Smith. Barbour Point to the next point south, Bangham, no. 489. A coarse herb 1-2 m. high, with broad cannalike leaves and orange flowers.

\section{MORACEAE}

Ficus Oerstediana Miq. Drayton Cabin to the second point north, Bangham, no. 509. A small tree with short broad leaves. The fruits are the smallest produced by any Central American species of Ficus.

Ficus padifolia HBK. Shores of the lake south of the laboratory, Bangham, no. 444. A tree $8 \mathrm{~m}$. high, with small fruits and small narrow leaves. This is the most common wild fig of Mexico and Central America, but, strangely enough, it has not been reported previously from the Canal Zone.

\section{LORANTHACEAE}

Oryctanthus spicatus (Jacq.) Eichl. Without data, Bangham, no. 421. A parasitic shrub, the small flowers sunken in the rachis of the short spike.

Phthirusa pyrifolia (HBK.) Eichl. Near the lake, Bangham, no. 441. A parasitic shrub with oblong obtuse leaves.

\section{POLYGONACEAE}

Coccoloba changuinolana Standl. Bangham, no. 593. A tree of $12 \mathrm{~m}$., known only from the Atlantic coast of Panama and Costa Rica, and not reported previously from the Canal Zone.

\section{MENISPERMACEAE}

Odontocarya truncata, sp. nov.

Frutex scandens, ramulis gracilibus glabris, vetustioribus ochraceis, novellis lenticellis magnis pallidis elongatis conspersis, internodiis elongatis. Folia longe petiolata, alterna, petiolo gracili glabro circa $3.5 \mathrm{~cm}$. longo; lamina subcoriacea, glabra, late ovata vel rotundato-ovata, $9-10.5 \mathrm{~cm}$. longa, 6-7 cm. lata, apice abrupte acuminata, acumine anguste triangulari 1-1.5 cm. longo attenuato obtusiusculo, basi truncata, utrinque glabra, supra viridis, costa nervisque obscuris, subtus paullo pallidior, basi 5nervia, costa nervisque gracilibus prominentibus, nervulis prominulis laxe reticulatis. Flores feminei racemosi, racemis axillaribus solitariis circa $6 \mathrm{~cm}$. longis, $7 \mathrm{~cm}$. longe pedunculatis, rhachi gracili glabra, pedicellis gracilibus rectis in statu fructifero 9-11 mm. longis. Drupae ovales luteae, circa $1.5 \mathrm{~cm}$. longae et $1 \mathrm{~cm}$. latae; endocarpium dorso rotundatum convexum, facie ventrali valde concavum.

Panama: Barro Colorado Island, Canal Zone, Armour house to second bay north, W. N. Bangham, no. 541, September 3, 1929 (Herb, Field Mus. No. 604,409, type; duplicate in herb. Arnold Arb.).

Like most of the other Menispermaceae at present recorded from Central America, this plant is known only from incomplete material, and its true 
generic position is therefore not altogether certain. From the described species of Odontocarya, two of which are known from the Isthmus of Panama, the plant here named differs in having truncate rather than cordate leaf blades.

\section{MONIMIACEAE}

Siparuna guianensis Aubl. Shore of the lake south of the laboratory, Bangham, no. 457. A shrub with red fruits and nearly glabrous leaves. Called "hierba de pasmo" in some parts of Panama.

\section{CAPPARIDACEAE}

Cleome Houstoni R. Br. Near the end of Pearson Trail, Bangham, no. 576. A spiny herb, the leaves with five leaflets.

\section{ROSACEAE}

Hirtella triandra Sw. Along the shore, Bangham, no. 398. A small tree of $6 \mathrm{~m}$., the flowers white or pink.

\section{CONNARACEAE}

Connarus Turczaninowii Triana \& Planch. Along the lake shore, Bangham, no. 418; Wetmore \& Woodworth, no. 26. A large woody vine with yellow flowers; leaves with five leaflets.

\section{LEGUMINOSAE}

Entada polystachia (L.) DC. Shore of the lake south of the laboratory, Bangham, no. 453. A large woody vine with small greenish flowers in dense panicled spikes; pods large and broad, the compressed seeds $\mathcal{Q} \mathrm{cm}$. broad.

Inga cocleensis Pittier. Between Drayton Cabin and Armour Cabin, Bangham, no. 528. A tree of $10 \mathrm{~m}$. Not recorded heretofore from the Canal Zone. No less than 14 species of Inga are now known to occur on Barro Colorado Island.

Inga confusa Britt. \& Rose. Between Drayton Cabin and Armour Cabin, Bangham, no. 516. A tree of $12 \mathrm{~m}$. with white flowers.

Inga gracilipes Standl. Between the Drayton and Armour cabins, Bangham, no. 522; Barbour Point to the next point south, Bangham, no. 488. A tree of $7 \mathrm{~m}$.; flowers in small umbels. The species is known only from the Canal Zone.

Inga laurina (Sw.) Willd. Armour Cabin to the second bay north, Bangham, no. 547. A tree $8 \mathrm{~m}$. high; leaflets only two or three pairs; flowers very small; pods small, thin, glabrous.

Inga pauciflora Duchass. \& Walp. On the lake shore, Bangham, no. $395 \mathrm{a}$.

\section{BURSERACEAE}

Protium Salvozae, sp. nov.

Arbor 4-8-metralis, ramulis gracilibus subteretibus brunnescentibus 
ubique dense velutino-hirtellis, internodiis elongatis. Folia petiolata, pinnata 5-foliolata, petiolo $2-3 \mathrm{~cm}$. longo gracili subtereti dense hirtello, rhachi $1.8-3 \mathrm{~cm}$. longa, petiolulis $4-8 \mathrm{~mm}$. longis (in foliolo terminali usque ad $2 \mathrm{~cm}$.) dense hirtellis; foliola crasse membranacea, oblonga vel lanceolato-oblonga, $7-12 \mathrm{~cm}$. longa, $2.5-4.5 \mathrm{~cm}$. lata, inferiora paullo minora, subabrupte acuminata, acumine $1 \mathrm{~cm}$. longo et ultra angusto attenuato obtuso, basi acuta et saepe paullo inaequalia, integra, fere concoloria, utrinque ad venas costamque pilis brevibus rigidiusculis patentibus dense hirtella, aliter glabra vel glabrata, costa venisque supra vix prominulis, subtus prominentibus, venis utroque latere c. 12, angulo lato adscendentbus, gracilibus, versus apicem abrupte incurvis, juxta marginem conjunctis, nervulis subtus prominulis laxe reticulatis. Flores sessiles, spicati, spicis axillaribus simplicibus $1-2 \mathrm{~cm}$. longis solitariis, rhachi dense hirtella; fructus ruber, late ovoideus, glabratus, obtusus et apiculatus, $13-15 \mathrm{~mm}$. longus, 10-12 mm. latus, basi obtusus vel subrotundatus.

Panama: Barro Colorado Island, Canal Zone, between Drayton and Armour cabins, W. N. Bangham, no. 513, September 2, 1929 (Herb. Field Mus., No. 606,248, type; duplicate in herb. Arnold Arb.); near Cabin 2, Barro Colorado Island, F. M. Salvoza, no. 948, September 2, 1929 (Herb. Arnold Arb.).

From P. sessiliflorum (Rose) Standl. of Panama, which likewise has sessile flowers, the present species differs in its simple flower spikes and pubescent leaflets. P. asperum Standl., described from Barro Colorado Island, has very scabrous rather than hirtellous leaflets.

\section{MELIACEAE}

Trichilia tuberculata (Triana \& Planch.) C. DC. On the lake shore, Bangham, no. 434. A tree $7 \mathrm{~m}$. high. Called "alfaje" at Chepo, Panama.

\section{MALPIGHIACEAE}

Bunchosia nitida (Jacq.) DC. Between Drayton and Armour cabins, Bangham, no. 518. A shrub $2 \mathrm{~m}$. high. The species is new to the Canal Zone.

Spachea elegans Juss. Near Pearson Trail, Bangham, no. 579. A tree $8 \mathrm{~m}$. high. The genus is new to Central America, nor has it been found elsewhere on the continent. It occurs in the West Indies.

Stigmaphyllon hypargyreum Triana \& Planch. Barbour Point to the next point south, Bangham, no. 496. A vine with yellow and red flowers.

\section{VOCHYSIACEAE}

Vochysia ferruginea Mart. On the lake shore south of the laboratory, Bangham, no. 452 . A tree $7 \mathrm{~m}$. high with showy yellow flowers in panicles.

\section{EUPHORBIACEAE}

Omphalea diandra L. Drayton Cabin to the second point north, 
Bangham, no. 504; Wetmore \& Woodworth, no. 58. A large woody vine with a fleshy yellow fruit as large as an orange; petioles with two glands at the apex.

\section{ANACARDIACEAE}

Mosquitoxylum jamaicense Krug \& Urban. Shore of the lake, Bangham, no. 426. A tree $7 \mathrm{~m}$. high with softly pubescent, pinnate leaves, the small fruits red. The genus is new to the Canal Zone.

\section{SAPINDACEAE}

Paullinia fimbriata Radlk. East shore, Salvoza, no. 908; lake shore south of the laboratory, Bangham, no. 446. A large woody vine with white flowers; leaflets 5 ; leaf rachis not winged. The species has not been recorded previously from the Canal Zone.

Serjania mexicana Willd. Wetmore \& Woodworth, no. 46.

\section{ELAEOCARPACEAE}

Sloanea microcephala Standley in Field Mus. Bot. 4: 152. 1929. The following additional collection may be reported: Between Drayton and Armour cabins, Bangham, no. 515. A tree $10 \mathrm{~m}$. high with yellow flowers.

\section{BOMBACACEAE}

Hampea panamensis Standl. Between Drayton and Armour cabins, Bangham, no. 520. A tree $12 \mathrm{~m}$. high, with small white flowers. The genus has not been collected previously in the Canal Zone.

Quararibea pterocalyx Hemsl. Near Pearson Trail, Bangham, no. 581. A tree with large white flowers, the long calyx bearing 10 narrow vertical wings.

\section{DILLENIACEAE}

Doliocarpus brevipedicellatus Garcke. On the lake shore, Bangham, no. 400. Fruits red.

Saurauia Zetekiana, sp. nov.

Frutex vel arbor 5-metralis, ramulis crassiusculis glabris lenticellis minutis pallidis elevatis sparse conspersis, internodiis brevibus. Folia sparsa breviter petiolata, petiolo gracili 6-8 $\mathrm{mm}$. longo sparse lepidotofurfuraceo; lamina crasse membranacea, oblongo-elliptica vel late elliptica, $5.5-11.5 \mathrm{~cm}$. longa, $2.8-6 \mathrm{~cm}$. lata, abrupte breviterque acuminata, acumine anguste triangulari attenuato obtusiusculo, basi obtusa vel acutiuscula, fere ad basin grosse crenato-serrata, utrinque glabra, supra viridis, costa venisque non elevatis, subtus paullo pallidior, costa gracili elevata, nervis lateralibus utroque latere 5-8, angulo acuto adscendentibus, subarcuatis, marginem attingentibus, nervulis obscuris. Flores numerosi paniculati, paniculis densifloris $5 \mathrm{~cm}$. longe pedunculatis ca. $5 \mathrm{~cm}$. longis et aequilatis, ramis subdense minuteque ferrugineo-stellato-furfuraceis, pedicellis gracilibus $3-5 \mathrm{~mm}$. longis; sepala inaequalia late rotundata $1.5-2.5 \mathrm{~mm}$. longa extus sparse stellato-puberula; cetera ignota. 
Panama: Barro Colorado Island, Canal Zone, near Pearson Trail, $W$. N. Bangham, no. 578, September 8, 1929 (Herb. Field Mus. No. 604, 411, type; duplicate in herb. Arnold Arb.).

The genus is new to the Canal Zone flora, and, indeed, very few Saurauias grow at so low an elevation. The present species is easy of recognition because of its small glabrous leaves. It is named for Mr. James Zetek, whose work in establishing the laboratory on Barro Colorado Island has been so eminently successful.

\section{CLUSIACEAE}

Clusia odorata Seem. F. L. Island, Bangham, nos. 588, 577. A large shrub with pink flowers. This species probably includes all or most of the material reported from Panama as $C$. minor $\mathrm{L}$.

\section{FLACOURTIACEAE}

Casearia javitensis HBK. F. L. Island, Bangham, no. 587; lake shore south of the laboratory, Bangham, no. 443. A shrub or small tree with small white flowers and red fruits. Called "maúro" in Chiriqui, Panama.

\section{PASSIFLORACEAE}

Passiflora ambigua Hemsl. Lake shore south of the laboratory, Bangham, no. 466.

\section{RHIZOPHORACEAE}

Cassipourea podantha Standl. Lake shore, Bangham, nos. 566, 416. A tree 8-10 m. high. The species has not been reported from the Canal Zone, but probably it includes a large part of the material previously referred to $C$. elliptica Poir.

\section{COMBRETACEAE}

Combretum coccineum (Aubl.) Engl. \& Diels. Between Drayton and Armour cabins, Bangham, no. 527. A large woody vine with large dense spikes of fiery red flowers, extremely showy and handsome when in blossom.

\section{MYRTACEAE}

Myrcia gatunensis Standley in Field Mus. Bot. 4: 154. 1929. The type was collected on Barro Colorado by Professor L. A. Kenoyer. The following new collections may be reported: Barbour Point to the next point south, Bangham, no. 498; lake shore south of the laboratory, Bangham, no. 451. A shrub about $3 \mathrm{~m}$. high with white flowers.

Eugenia Banghamii, sp. nov.

Frutex 3-metralis, ramulis gracilibus subteretibus ferrugineo-brunneis glabratis, internodiis 1-2.5 $\mathrm{cm}$. longis. Folia breviter petiolata opposita, petiolo crassiusculo $3-4 \mathrm{~mm}$. longo dense breviterque pilosulo; lamina coriaceo-membraracea, oblongo-elliptica, $8-10 \mathrm{~cm}$. longa, 3-5 cm. lata, abrupte breviterque acuminata, acumine triangulari obtuso, basi obtusa 
vel acutiuscula, supra viridis, epunctata, ubique dense minuteque velutinopilosula, costa gracillima prominula, venis obscuris, subtus fere concolor, dense velutino-pilosula et pilis patentibus plus minusve intertextis, costa gracili elevata, nervis lateralibus utroque latere circa 9, angulo acuto adscendentibus, fere rectis, remote a margine conjunctis. Flores pauci ad axillas fasciculati, sessiles vel brevissime pedicellati, pedicellis usque ad 1 $\mathrm{mm}$. longis; calyx $3 \mathrm{~mm}$. latus, sepalis 4 rotundatis ciliolatis; baccae immaturae globosae, 3-4 mm. diam., densissime grosseque punctatae, glabrae, calyce persistente coronatae; cetera ignota.

Panama: Barro Colorado Island, Canal Zone, on shores of Gatún Lake south of the laboratory, W. N. Bangham, no. 448, August 28, 1929 (Herb. Field Mus. No. 604, 410, type; duplicate in herb. Arnold Arb.).

Although only scanty material is available for study, it seems to represent a clearly distinct species of this genus, notable for the abundant soft spreading pubescence of the leaves, and for the sessile or subsessile flowers.

Eugenia melanosticta, sp. nov.

Arbor 4-6-metralis, omnino glabra, ramulis crassiusculis, vetustioribus teretibus pallide cinnamomeis, novellis subcompressis albidis vel ochraceis undique glandulis magnis ovalibus nigris dense notatis, internodiis plerumque $2-3.5 \mathrm{~cm}$. longis. Folia breviter petiolata, opposita, petiolo crassiusculo 5-7 mm. longo supra sulcato; lamina coriacea, oblonga vel anguste elliptico-oblonga, 8-12 $\mathrm{cm}$. longa, $3.5-4.5 \mathrm{~cm}$. lata, breviter acuteque acuminata, basi acuta vel acutiuscula et brevissime decurrens, fere concolor, supra minutissime impresso-puncticulata, costa profunde impressa, venis obsoletis, subtus dense elevato-puncticulata, costa gracili elevata, venis obscuris. Inflorescentiae axillares solitariae, subracemosae, laxe pauciflorae, 1-2.5 cm. longe pedunculatae, pedicellis crassis 4-7 mm. longis; fructus basi bibracteolatus, bracteolis c. $1 \mathrm{~mm}$. longis rotundatis; bacca globoso-ovalis, $10-12 \mathrm{~mm}$. longa, $8-9 \mathrm{~mm}$. lata, basi et apice rotundata, calyce persistente coronata, densissime tuberculato-glandulosa; calyx $4.5 \mathrm{~mm}$. latus, 5 -lobus, lobis late rotundatis brevissimis.

Panama: Barro Colorado Island, Canal Zone, Shores of Gatún Lake south of the laboratory, W. N. Bangham, no. 445, August 28, 1929 (Herb. Field Mus. No. 606,247, type; duplicate in herb. Arnold Arb.); east shore of Barro Colorado Island, F. M. Salvoza, no. 909, August 28, 1929.

The material of this tree available for study is rather unsatisfactory, but it seems better referable to Eugenia than to any other group known from Central America, and it is perhaps worth while to give it a name in order to bring it to the attention of future students. The species is noteworthy for the very numerous and conspicuous black glands of the young branchlets.

\section{MELASTOMACEAE}

Miconia minutiflora (H. \& B.) DC. Barbour Point to the next point south, Bangham, no. 486. A shrub or small tree about $5 \mathrm{~m}$. high, with small white flowers. 


\section{SAPOTACEAE}

Lucuma glabrifolia Pittier? North shore near the end of Pearson Trail, Salvoza, no. 999 . A tree $10 \mathrm{~m}$. high with milky sap and a large, yellowish green fruit. The determination is very uncertain, because of the assence of flowers, and the tree may well represent an undescribed species.

\section{APOCYNACEAE}

Echites microcalyx A. DC. Barbour Point to the next point south, Bangham, no. 494. A slender vine; corolla yellow with red throat.

Echites trifida Jacq. On shore at the end of the island, Bangham, no. 573. A vine with greenish yellow flowers.

Prestonia macrocarpa Hemsl. Shore of the lake south of the laboratory, Bangham, no. 467; shore at the end of the island, Bangham, no. 569. A large woody vine.

\section{CONVOLVULACEAE}

Aniseia martinicensis (Jacq.) Choisy. F. L. Island, Bangham, no. 589. An herbaceous vine with narrow oblong obtuse leaves; corolla white.

\section{VERBENACEAE}

Aegiphila cephalophora Standley in Field Mus. Bot. 4: 156. 1929. Type collected on Barro Colorado by Professor Leslie A. Kenoyer. Another collection may now be reported: Armour Cabin to the second bay north, Bangham, no. 543x.

\section{SOLANACEAE}

Solanum Hayesii Fernald. Between Drayton and Armour cabins, Bangham, no. 514; Drayton Cabin to the second point north, Bangham, no. 501. A prickly tree about $7 \mathrm{~m}$. high with white flowers. The species is known only from the Canal Zone.

Markea panamensis, sp. nov.

Frutex scandens, ramulis crassiusculis ochraceis vel brunnescentibus subteretibus, internodiis plerumque elongatis, floriferis vulgo dense foliatis vel cicatricibus foliorum delapsorum dense notatis. Folia breviter petiolata, alterna vel subopposita, petiolo crassiusculo 7-13 $\mathrm{mm}$. longo glabro supra sulcato; lamina pergamentacea, oblanceolato-oblonga vel obovato-oblonga, 8-14 cm. longa, 3-4 cm. lata, acuta et abrupte cuspidatoacuminata, acumine angusto attenuato, versus basin acutam vel acuminatam sensim angustata, utrinque glabra, integra, costa nervisque supra vix elevatis inconspicuis, subtus paullo pallidior, costa gracili elevata, nervis lateralibus utroque latere circa 7, angulo acuto latove adscendentibus, gracillimis, prominulis, margine saepe subrevoluto. Flores ad apices ramulorum fasciculati vel breviter racemosi, pedicellis gracilibus $5-10 \mathrm{~mm}$. longis furfuraceo-puberulis vel glabratis; calyx viridis fere ad basin 5-fidus, laciniis oblongis 5-9 $\mathrm{mm}$. longis acutiusculis vel obtusis sparse minuteque puberulis 3 -nerviis; corolla lutea infundibuliformis, $1.5 \mathrm{~cm}$. longa, extus minutissime 
puberula, 5-nervia, tubo $4 \mathrm{~mm}$. longo $1.2 \mathrm{~mm}$. crasso, fauce $7 \mathrm{~mm}$. longa, ore $6 \mathrm{~mm}$. lata, lobis 5 ovali-ovatis fauce paullo brevioribus obtusis. Bacca immatura ovoidea, $13 \mathrm{~mm}$. longa.

Panama: Barro Colorado Island, Canal Zone, Armour House to the second bay north, W. N. Bangham, no. 543, September 3, 1929 (Herb. Field Mus. No. 604,412, type; duplicate in herb. Arnold Arb.). Along the Sambú River, southern Darién, at sea level, H. Pittier, no. 5566, February, 1912.

The plant is noteworthy in the genus for its very small flowers. It could be referred equally well, probably, to the genus Merinthopodium Donn. Smith, whose distinctness from Markea is open to question.

\section{BIGNONIACEAE}

Anemopaegma punctulatum Pitt. \& Standl. Across the bay from Drayton Cabin, Bangham, no. 544; also Wetmore \& Woodworth, no. 40 . A large woody vine with showy yellow flowers.

Arrabidaea panamensis Sprague. Shore of the lake south of the laboratory, Bangham, no. 449. A woody vine with small, pale lavender flowers.

Petastoma breviflorum, sp. nov.

Frutex scandens, ramis gracilibus teretibus ochraceis striatis lenticellis paucis parvis elevatis conspersis, novellis sparse pilosulis cito glabratis, internodiis elongatis. Folia bifoliolata, opposita, $8-14 \mathrm{~mm}$. longe petiolata, petiolo gracili dense breviterque piloso, petiolulis $8-15 \mathrm{~mm}$. longis gracilibus pilosis; foliola late elliptica, $6.5-9.5 \mathrm{~cm}$. longa, $3-6.5 \mathrm{~cm}$. lata, abrupte acuta vel acuminata, acumine triangulari vel anguste triangulari attenuato acuto vel obtuso, basi obtusa vel rotundata, crasse membranacea, fere concoloria, luteo-viridia, supra glabra, sparse et minutissime pallidopuncticulata, nervis prominulis, subtus ubique sed praesertim ad venas pilis mollibus albidis sparse pilosa, costa nervisque elevatis, nervulis prominulis et reticulatis. Paniculae terminales subdense multiflorae foliis vix longiores, ramulis gracilibus dense breviterque pilosis, floribus graciliter pedicellatis; calyx extus sparse puberulus vel fere glaber, $5 \mathrm{~mm}$. longus et aequilatus, parte inferiore turbinata, limbo patelliformi remote obscureque denticulata; corolla purpurea, tubo $5-6 \mathrm{~mm}$. longo gracili tereti $2 \mathrm{~mm}$. crasso extus glabro, fauce campanulata $6 \mathrm{~mm}$. longa ore circa $8 \mathrm{~mm}$. lata extus glabra, lobis subaequalibus ovalibus $6 \mathrm{~mm}$. longis apice rotundatis extus et intus densissime puberulo-tomentosis; stylus gracilis glaber. Capsula immatura linearis compressa, $26 \mathrm{~cm}$. longa et ultra, $8 \mathrm{~mm}$. lata, glabra, basin versus paullo angustata.

Panama: Barro Colorado Island, Shores of Gatún Lake, south of the Laboratory, $W . N$. Bangham, no. 465 in part, August 28, 1929 (Herb. Field Mus. no. 604,413, type); lake shore near the laboratory, W. N. Bangham, no. 553, September 3, 1929 (Herb. Arnold Arb.).

Bangham no. 465, as represented in the herbarium of Field Museum, consists of a mixture of two quite distinct plants. The flowering specimens are Arrabidaea panamensis Sprague, while the specimens with young fruit belong to the species here described.

Petastoma breviflorum is evidently an ally of $P$. patelliferum, having the same peculiarly distributed pubescence on the corolla, but the flowers of $P$. breviflorum are very much smaller than those of the latter species. 


\section{$2 \mathrm{BHL}$ Biodiversity Heritage Library}

Standley, Paul Carpenter. 1930. "A second supplement to the flora of Barro Colorado Island, Panama." Journal of the Arnold Arboretum 11(2), 119-129. https://doi.org/10.5962/bhl.part.2812.

View This Item Online: https://www.biodiversitylibrary.org/item/33588

DOI: https://doi.org/10.5962/bhl.part.2812

Permalink: https://www.biodiversitylibrary.org/partpdf/2812

\section{Holding Institution}

Missouri Botanical Garden, Peter H. Raven Library

\section{Sponsored by}

Missouri Botanical Garden

\section{Copyright \& Reuse}

Copyright Status: In copyright. Digitized with the permission of the rights holder.

Rights Holder: Arnold Arboretum of Harvard University

License: http://creativecommons.org/licenses/by-nc-sa/3.0/

Rights: https://biodiversitylibrary.org/permissions

This document was created from content at the Biodiversity Heritage Library, the world's largest open access digital library for biodiversity literature and archives. Visit BHL at https://www.biodiversitylibrary.org. 